\title{
中國醫改實踐的生命倫理學困境 與中國結構性倫理學視角
}

劉繼同張東奇

\section{摘要}

改革開放以來, 中國醫藥衙生體制改革實践面臨諸多問題, 其中包括政治、經濟、社會、文化和倫理議題。醫護人員的價值 觀念、道德判斷、行為規範和專業精神的危機集中體現在生命倫 理學結構性困境狀況之中。現時中國醫患關係空前絕後的結構性 緊張狀況正是最典型的例證。本文試圖從中國道德哲學、道德社 會史、中國社會史和醫學社會史等視角, 運用文獻回顧、衞生政 策比較研究和案例分析等方法, 回顧西方倫理學史及其個人主義 生命倫理學典範之歷史演變; 並在中國社會結構性轉型與醫藥衞 生體制改革的宏觀社會處境下, 分析中國道德哲學和生命倫理學 的思想傅統及其面臨的挑戰。文章根據醫藥衞生體制改革和生命 倫理學實践, 提出具中國特色的 “結構性倫理學和結構性生命倫 理學”。作者試圖闡述“結構性倫理學與結構性生命倫理學”體 系的內涵外延、構成要素、範圍內容、基本特點和結構性成因, 尤其是這種體系對目前中國醫藥衝生體制改革政策之意義。

劉繼同, 北京大學公共衞生學院衞生政策與管理系副教授, 中國北京, 郵編：100191。 張東奇, 北京大學公共衞生學院衞生政策與管理系碩士生, 中國北京, 郵編：100191。

《中外醫學哲學》IX:2 (2011年) : 頁 91-108。

(C) Copyright 2011 by Global Scholarly Publications. 
【關鍵字】中國醫改 生命倫理學 中國道德哲學 群體倫理學 結構性倫理學

\section{一、中國醫藥衞生體制改革實踐與生命倫理學的 結構性困境}

改革開放三十二年以來, 中國醫藥衞生體制改革實踐面臨愈來 愈多政治、法律、經濟、社會、文化、精神心理、倫理道德等問題 和爭議, 如醫改的醫學哲學基礎、生物醫學與社會理論視角、醫學 專業精神和生命倫理學的系統性和結構性困境等, 都成為最有待解 決的社會議題 ${ }^{1}$ 。2010年是中國的 “社會福利元年” ，標誌著中國從 此進入社會立法、社會政策與社會福利時代。尤其在 “以改善民生為 重點的社會建設時代”（中國共產黨第十七次全國代表大會，2007） 和構建和諧社會、和諧世界的宏觀社會背景下, 醫藥衞生政策成為 新型的 “國策” 2 。現今醫護人員行為與社會期望之差距日益擴大, 國 民對 “看病難、看病貴” 的容忍度已達極限, 中國醫藥衞生體制改革 醫學倫理學與生命倫理學的系統性與結構性困境, 格外引人注目。3 不言而喻, 這種結構性困境體現在醫療服務所有領域, 其中有六個 方面特別值得關注：一是醫學哲學與醫學目的出現系統性與結構性 異化，醫療服務實踐的目標亟需重新定位。 ${ }^{4}$ 二是醫學價值觀與專業 精神出現結構性扭曲, 公民權利、國家責任和健康公平理念薄弱。 ${ }^{5}$ 三 是醫療衞生服務性質由改革前單一的 “社會福利” 性質, 轉為二元化

(1) 許志偉 : 〈中國當前的醫療危機與醫護人員的專業責任和使命〉, 《醫學與哲學》, 2006 年, 第 9 期, 頁 1 。

(2) 劉繼同：〈為甚麼衞生政策還不能成為“國策”? ?, 《中國衞生》, 2004 年, 第 7 期, 頁 51 。

（3）邱仁宗：〈第八屆世界生命倫理學大會關於醫學專業精神和醫患關係研討內容綜 述〉, 《中國醫學倫理學》, 2007 年, 第 2 期, 頁 4 。

(4) 劉繼同: 〈醫學目的、衞生改革目標與建構和諧社會〉, 《西安外事學院學報》, 2006 年, 第 2 卷, 第 2 期, 頁 $17-23$ 。

(5) 劉繼同: 〈衞生改革的價值基礎與價值目標的宏觀戰略思考〉, 《衞生經濟研究》, 2006 年, 第 3 期, 頁 3 。 
的福利與公益事業。 ${ }^{6}$ 四是醫療衞生服務收費機制由改革前免費和公 費醫療, 轉為以病人現金市場化籌資為主。 ${ }^{7}$ 五是醫護人員與病人家 屬關係由改革前專業代理關係, 轉為目前直接和赤裸裸的經濟關係。8 六 是醫療衞生行政管理體制多頭分隔和企業管理, 醫務人員專業權威 與國家行政權威衝突。簡言之, 中國醫改實践生命倫理學的系統性 與結構性困境是世界罕見的, 導致緊張的醫患關係, 如殺害、傷害、 圍攻、謾駡醫護人員和醫療糾紛頻發等便是具體例子 9 。

\section{二、西方個人主義生命倫理學之歷史演變及其特點}

綜觀人類社會尤其是西方國家道德哲學與倫理學發展歷史，我 們可以清晰看到西方國家道德哲學和倫理學演變之歷史軌跡。這種 軌跡的主題是以個人為基礎的個人主義倫理學, 其精髓是個人道 德。按照麥金太爾(Alasdair MacIntyre)的劃分，西方國家的道德哲學 與倫理學模式可以劃分為““善”的前哲學階段”，“古希臘羅馬時 期”，“中世紀基督教階段”，“近代工業革命時期”，“現代社 會” 和“後現代” 六個時期。 ${ }^{10} 20$ 世紀 70 年代 “生命倫理學”誕生， 標誌以多元性和個人權利為基礎的生命倫理學時代來臨。 ${ }^{11}$ 西方國 家把倫理學史劃分為六個發展階段, 主要目的是方便建構分析框 架。因每個時期的宏觀社會環境、道德哲學思想、主流核心價值、 國家形態、市場體系、階級結構、主要矛盾、行為主體、生活方式、 道德規範、社會評價和社會倫理模式的內涵都有所不同, 典型反映

(6) 劉繼同:〈衞生事業公益性與福利性定性的本質區別是甚麼? 〉, 《中國醫院管理》, 2007 年, 第 8 期, 頁 4 。

（7）劉繼同：〈中國醫藥衞生體制改革困境與“醫療財政學”問題〉, 《中共寧波市委黨 校學報》, 2008 年, 第 4 期, 頁 25 。

(8) 斯科特. 伯里斯(Scott Burris)著, 申衛星主編: 《中國衞生法前沿問題研究》(北 京: 北京大學出版社, 2005 年), 頁 10 。

(9) 孫樹印：〈新形勢下醫患糾紛處理模式探討〉, 《中醫藥管理雜誌》, 2011 年, 第 1 期, 頁 8 。

(10) 麥金太爾 (Alasdair MacIntyre) 著, 龔 群譯 : 《倫理學簡史》(北京 : 商務印書館, 2003 年)，頁 7-20。

(11) 恩格爾哈特 (H. Tristram Engelhardt, Jr.) 著, 范瑞平譯 : 《生命倫理學基礎 (第二版)》 (北京：北京大學出版社, 2006 年), 頁 v-vii。 
著每個時期的社會生活與倫理道德實踐, 社會、國家與個人之間互 動關係，社會主要矛盾與社會需要滿足體系之間關係，以及道德哲 學體系結構性變遷規律。

\begin{tabular}{|c|c|c|c|c|c|c|}
\hline 分析層面 & 前哲學階段 & 古希臘時期 & 中世紀教會 & 工業化革命 & 現代化社會 & 後現代社會 \\
\hline 歷史階段 & BC5世紀前 & BC5-5世紀 & 6-16世紀 & 17-19世紀 & 20世紀 & 21世紀 \\
\hline 社會性質 & 原始社會 & 奴隸社會 & 封建社會 & 工業社會 & 現代社會 & 後現代社會 \\
\hline 道德哲學 & 善的前哲學 & 生活美德 & 基督之愛 & 功利主義 & 個人主義 & 全球倫理 \\
\hline 價值觀念 & 自然觀念 & 至善生活 & 上帝之愛 & 理性契約 & 人文主義 & 全人發展 \\
\hline 國家形態 & 部落國家 & 城邦國家 & 宗教國家 & 經濟國家 & 福利國家 & 新型國家 \\
\hline 市場體系 & 社會交換 & 高度發垟 & 緩慢發展 & 自由市場 & 市場經濟 & 成熟市場 \\
\hline 階級結構 & 群體差異 & 階級矛盾 & 政教合 & 階級鬥爭 & 社會分層 & 階級平等 \\
\hline 倫理問題 & 無足輕重 & 社會議題 & 宗教議題 & 人性議題 & 核心議題 & 道德哲學 \\
\hline 行為主體 & 氏族部落 & 城邦公民 & 宗教信徒 & 個人法人 & 公民個人 & 全球公民 \\
\hline 生活方式 & 自然維生 & 美德生活 & 宗教生活 & 經濟生活 & 品質生活 & 意義生活 \\
\hline 道德規範 & 崇拜禁忌 & 美德智慧 & 信仰虔誠 & 人性功利 & 社會契約 & 個性自由 \\
\hline 社會評價 & 風俗習慣 & 直覺主義 & 宗教倫理 & 功利主義 & 個人主義 & 個人權利 \\
\hline 倫理模式 & 自然倫理 & 生活方式 & 神聖戒律 & 經濟人型 & 個人主義 & 多樣化型 \\
\hline
\end{tabular}

表 1 : 西方國家道德哲學與倫理學模式歷史發展演變狀況一覽表

總體來説，西方國家道德哲學與個人主義倫理學模式的歷史發 展和結構演變軌跡清晰, 其道德哲學與倫理學模式發展呈現若干顯 著特點。首先, 相對東方和中國來説, 西方社會發展經歷原始社會、 奴隸社會、封建社會、工業社會和後現代社會等多種社會形態, 其 道德哲學與倫理學模式的類型也多種多樣。其次，西方社會道德哲 學的歷史淵源深厚, 倫理學的理論基礎多樣, 例如古代風俗習慣法, 不僅包括中國在內的世界各民族風俗習慣，也發展出猶太教、基督 教、伊斯蘭教等宗教倫理。12 第三，西方國家宗教哲學、宗教性道 德哲學和宗教倫理學異常發達, 尤其是儀式化與制度化宗教信仰， 及萬物有靈和高層次的靈性生活，為西方道德哲學和倫理學奠定多

(12) 梅 因 (Sir Henry Sumner Maine)著, 沈景一譯 : 《古代法》（北京：商務印書館，1984 年), 真 3-5。 
方面基礎。13 第四, 由於西方社會發展形態、社會制度安排、道德 哲學思想、倫理價值觀念、倫理道德實踐和行為規範的多樣性，及 人性理論與社會制度、個人主義與集體主義等倫理兩難爭論議題, 導致西方社會道德哲學發達, 倫理學理論研究模式眾多, 道德哲學 與倫理研究長盛不衰。14 第五, 西方社會道德哲學與倫理學模式, 由原始社會的“群體倫理學”，經過古希臘時期 “公民群體個性主義 倫理學”，尤其是中世紀基督教“信仰共同體宗教倫理學”階段，在 文藝復興、啟蒙運動、工業化革命和更高發展水準處境下，回歸 “全 民性個人主義倫理學”，典型反映西方社會文化的本質。15

\section{三、中國道德哲學、社會結構性轉型與群體為基礎的 倫理學}

中華民族多元統一，五千年文明源遠流長，發展出深厚、豐富 的道德哲學與倫理思想, 其價值觀念與倫理實踐深刻影響日本、韓 國, 是東方的哲學代表。春秋戰國時代, 中國哲學人才輩出, 百家 爭鳴, 傳統哲學與道德哲學空前繁榮。秦始皇焚書坑儒, 尤其漢武 帝 “罷黜百家、獨尊儒術” 、董仲舒為其策劃治國方略以後, 長期以 來戰亂不斷、軍閥割據、民不聊生的環境，為佛教思想的盛行營造 適宜的社會環境。宋代發展出以程頣、朱喜為代表的“程朱理學”, 標誌封建道德哲學和倫理思想達到新高度。元明時代以來, 西方基 督宗教通過探險、戰爭、經商、傳教和正常文化交流等方式進入中 國, 基督教哲學與倫理學成中國傳統道德哲學與倫理學體系的重要 組成部分, 且影響日增。16 1840 年鴉片戰爭後, 通過口岸條約和醫

(13) 查理斯· L · 坎默(Charles L. Kammer III) 著, 王穌平譯 : 《基督教倫理學》(北京 : 中國社會科學出版社, 1994 年), 頁 3。

(14) 亞里斯多德 (Aristotle)著, 苗力田譯: 《尼各馬科倫理學》（北京：中國社會科學 出版社, 1990 年), 頁 1 。

(15) Machan, Tibor R. Classical Individualism: The Supreme Importance of Each Human Being (London: Routledge, 1998) I-II.

(16) 中國社會科學院哲學研究所《哲學研究》編輯部、中國哲學史研究室編：《中國 哲學史研究集刊(第二輯)》(上海：上海人民出版社, 1982 年), 頁 12-15。 
療傳教, 基督宗教哲學與倫理學影響顯著擴大。 ${ }^{17} 1911$ 年辛亥革命 尤其是五四“新文化運動”後，西方自由、民主、平等、科學等價值 觀念, 以及 “前蘇聯” 和馬克思主義思想傳入中國, 馬克思主義、新 民主主義革命和革命道德應運而生。中國道德哲學和倫理，西方基 督宗教倫理與現代個人主義倫理與共產黨的革命倫理融為一體。1949 年新中國成立後, 前蘇聯和社會主義道德觀念和倫理思想成為中國 主流道德規範。18 改革開放以來, 一方面中國重新融入世界大家庭, 西方個人主義價值觀念與倫理影響激增，另一方面中國傳統道德哲 學與倫理思想處於全面結構性轉型過程中, 新型倫理學呼之欲出。

\begin{tabular}{|c|c|c|c|c|c|c|}
\hline 分析層面 & 儒家倫理 & 佛教倫理 & 道家倫理 & 基督教倫理 & 商業倫理 & 馬克思倫理 \\
\hline 歷史階段 & 春秋戰國 & 東漢以後 & 三國以後 & 1840 年後 & 1840年後 & 1919前後 \\
\hline 社會性質 & 奴隸社會 & 封建社會 & 封建社會 & 半殖民地 & 半殖民地 & 現代社會 \\
\hline 道德哲學 & 諸子百家 & 儒佛哲學 & 儒釋道家 & 耶儒釋道 & 耶儒釋道商 & 耶儒釋道馬 \\
\hline 倫理性質 & 情理倫理 & 善緣倫理 & 養生倫理 & 宗教道德 & 經濟道德 & 革命道德 \\
\hline 價值觀念 & 天人合一 & 生死輪回 & 修身養性 & 博愛世人 & 誠信公平 & 集體主義 \\
\hline 國家形態 & 城市國家 & 封建帝國 & 封建帝國 & 半封建國家 & 半殖民國家 & 現代國家 \\
\hline 市場體系 & 商品交換 & 自給自足 & 自給自足 & 市場萌芽 & 市場萌芽 & 市場經濟 \\
\hline 階級結構 & 階級分化 & 階級分層 & 結構穩定 & 新階級分化 & 新階級分化 & 新階級分層 \\
\hline 倫理問題 & 格外突出 & 生命倫理 & 倫理社會 & 東西衝突 & 公私衝突 & 核心地位 \\
\hline 行為主體 & 士農貴族 & 普通百姓 & 農民貴族 & 士農工商 & 士農工商 & 士農工商知 \\
\hline 生活方式 & 自然和諧 & 慈悲為懷 & 自愛養生 & 社會利他 & 在商言商 & 革命鬥爭 \\
\hline 道德規範 & 中庸之道 & 積德行善 & 自我完善 & 社會服務 & 優勝劣汰 & 奉獻犲羲牲 \\
\hline 社會評價 & 家國一體 & 善亞報應 & 獨善其身 & 社會責任 & 商業成敗 & 革命解放 \\
\hline 倫理模式 & 生活情理 & 功德圓滿 & 自我發展 & 社會倫理 & 職業道德 & 革命道德 \\
\hline
\end{tabular}

表 2：中國道德哲學與倫理學模式歷史發展演變狀況一覽表

總體來説, 中國傳統文化、道德哲學與倫理思想體系具有若干 不同於西方國家的特徵。其中最大特點是中國社會發展階段較少，

(17) 李傳斌：《條約特權制度下的醫療事業：基督教在華醫療事業研究(1835-1937)》 （長沙：湖南人民出版社, 2010 年）, 頁 1-3。

（18）張錫勤、饒良倫、楊忠文編著：《中國近現代倫理思想史》(哈爾濱：黑龍江人民 出版社, 1984 年), 頁 2-3。 
處於現代化建設過程中, 社會形態較少, 社會發展層次較低, 道德 哲學、倫理思想與生活實踐經驗不如西方種富多彩。其次, 中國道 德哲學與倫理思想淵源多樣, 基本形成本土化和封建社會的儒釋 道, 由西方傳入的基督教和資本主義倫理學, 及馬克思主義和革命 化倫理道德, 成為 “三足鼎立” 的局面。19第三, 從道德哲學與倫理 思想角度看, 中國傳統文化、道德哲學和倫理思想的 “理論體系與道 德哲學” 思考相對較弱，實乏完整、系統的理論闡述，貫乏現代價值 觀念, 如公民權。20 最後, 1840 年以來, 中國社會環境、社會需要、 社會結構、道德哲學和行為規範發生翻天覆地變化, 政治、經濟革 命、社會、文化革命與道德革命相互影響, 群體倫理模式成為主流。

\section{四、結構性倫理學的涵義、要素、範圍內容、特點與成因}

結構性倫理學的基本涵義由兩大部分組成，關鍵是結構主義概 念的界定取向和理解。眾所周知，結構主義是 20 世紀社會理論的重 要組成部分，涉及社會學、語言學、人類學、發展心理學和生物學 等眾多專業學科，而且每種專業學科視角對結構主義的理解迥然不 同。儘管如此，從社會科學與社會理論的角度看，結構主義的四個 系統性特徵正是我們所強調的，一是倡導“整體論”觀點，主要主張 一個系統的不同部分不應相互獨立地加以分析研究。二是始終以探 尋穩定不變的社會結構為主要目標，基本主張是社會結構決定社會 行動和意義。三是反對實證主義理論和方法論，基本主張是可觀察 的社會現象背後存在更深層次的結構。四是最重要特徵是社會結構 約束性質，主張社會結構廣泛和深刻制約人們行動與思想。21 綜前 所述，本文所謂的結構主義是以社會學與社會理論為視角，旨在強

(19) 范瑞平：〈導言：中國生命倫理學研究：良好開端, 大有可為〉, 《中外醫學哲 學》, 2007 年 12 月, 第 5 卷, 第 2 期, 頁 $1-8$ 。

(20) 馬歇爾 (Thomas H. Marshall)著, 劉繼同譯：《公民權與社會階級》（北京：國外 社會學, 2003 年第 1 期)，頁 4 。

(21) 派翠克 ·貝爾特(Patrick Baert)著, 翟鐵鵬譯 : 《二十世紀的社會理論》(上海 : 上 海譯文出版社, 2002 年) , 頁 2 。 
調社會結構功能與作用。實際上, 本文結構主義等同於結構性取向。 顧名思義, 結構性倫理學是從社會結構角度理解人們道德觀念與行 為規範的學科。簡言之, 結構性倫理學並非純粹的理論創新, 而是 中國醫改實踐倫理困境的必然性產物。

總體來説, 結構性倫理學體系的構成要素與主要組成部分共有 六個方面, 典型反映了結構性倫理學體系的結構性特徵和系統性思 考, 尤其是人性論、道德哲學和制度化建設關係。首先, 結構性倫 理學的道德哲學是存在主義取向的, 即人們的道德觀念、道德風尚、 道德規範、道德品質是 “客觀存在” 的社會現象, 是客觀現實與主觀 現實社會的高度整合。這意味著日常生活現實尤其人們的道德規 範, 是觀念世界與客觀世界互動的社會產物。其次, 結構性倫理學 的性質是社會現實主義, 而非理想主義, 是集體主義, 而非個人主 義, 是社會系統性, 而非單獨個體化思考, 是人性論與制度化建設 高度整合, 而非割裂的體系。第三, 結構性倫理學主要研究目標不 僅是 “應當” 和人們據以推斷他們應當做甚麼的程式, 更為重要是要 研究人們日常生活的實際行為和道德規範的客觀存在是甚麼, 而且 道德觀念、道德風尚、道德規範、道德品質的 “社會客觀存在”更加 重要, 因為是理解行為規範的基礎。22第四, 結構性倫理學的研究 範圍廣泛, 內容繁多, 研究範圍不僅包括宏觀社會環境與歷史、文 化傳統和道德哲學, 還包括個人生存發展社會環境、制度安排、政 策框架與服務體系, 更重要是研究個人道德觀念、道德風尚、道德 規範與更宏大社會環境間的互動關係模式。23 換言之, 結構性倫理 學關注道德的直覺主義與功利主義, 經驗主義與主觀主義的高度統 一。結構性倫理學的基本特徵是將道德哲學與道德規範放在宏觀社 會環境與社會結構中考察。第五, 結構性倫理學的研究視角不僅僅 是局限於哲學分析、道德哲學和倫理學專業學科, 而應從哲學、人

(22) 享利·西季威克(Henry Sidgwick)著, 廖申白譯: 《倫理學方法》（北京: 中國社 會科學出版社, 1993 年), 頁 23-38。

(23) 斯馬特(John J. C. Smart) 、威廉斯(Bernard Williams)著, 牟 斌譯：《功利主義： 贊成與反對》(北京：中國社會科學出版社, 1992 年), 頁 2。 
文社會科學, 從跨學科、跨行業、跨部門角度探尋道德哲學發展普 遍規律。第六, 結構性倫理學研究的主要功能作用不僅僅是 “解釋世 界”，更重要在於“改造世界”; 不僅是明辨是非，弘揚正氣，確立 善惡美醜的社會標準, 而且規範人們行為, 淨化人們心靈。最重要 是通過制度建設途徑, 為構建和諧社會、和諧人際關係與和諧醫患 關係貢獻力量。24簡言之, 結構性倫理學的要素是道德哲學、性質、 目標、範圍內容、方法和功能作用, 道德哲學主要回答道德本體論, 性質回答道德本質, 目標回答道德目的, 範圍內容回答倫理道德適 用範圍和物件, 方法回答道德改善途徑, 功能作用回答道德的社會 功能角色議題。25

結構性倫理學的研究範圍廣泛, 內容繁多, 覆蓋人類社會生活 與個人道德規範, 尤其是特定時間與特定空間處境下社會道德規範 與個人行為模式之間的互動關係。研究目標是探尋人類社會道德生 活的普世規律，總結道德生活模式發展演變的普遍性與特殊性，增 進人們對“客觀現實社會”與“主觀現實社會”統一體之生活邏輯的 認識和理解，探尋深刻影響人們的道德哲學、道德觀念、道德風尚、 道德規範和道德品質的社會決定性因素, 系統評估主流道德規範的 對社會的影響和後果，進而發展完善新型道德哲學理論體系。26

結構性倫理學基礎性議題與個人主義倫理學社會系統性和結構 性特徵截然不同，這也是本文關注的重點領域之一，因為基本特徵 的概括總結最能反映客觀現實生活的狀況。總體來説，結構性倫理 學基本特徵的直接和間接對照、參照、比較物件是個人主義倫理學, 而且這種比較的特點是從 “理想模式” 的角度進行，可能存在人為誇 大或不盡真實等情況。首先，結構性倫理學的基本特徵是 “社會性或 社會化”，而非“個體性或個體化”。儘管道德觀念、道德行為主體

(24) 趙美娟: : 醫學人文關懷應關懷甚麼和怎樣關懷——美學視角下的人文關懷建設〉, 《醫學與哲學》, 2005 年, 第 4 期, 頁 26 。

(25) Reimer, Joseph, Diana Pritchard Paolitto, Richard H. Hersh. Promoting Moral Growth: From Piaget to Kohlberg, $2^{\text {nd }}$ Ed. (New York: Longman, 1983) 1.

(26) 李 奇：《道德與社會生活》（上海：上海人民出版社, 1984 年）, 頁 $1-5$ 。 
的 “最基本單元” 是個人和個體，但是個體已是 “社會化的自我”。 我們通過社會化個人清晰 “看到” 社會總體, 或透過個人道德狀況 “折射” 社會總體狀況。27這意味個人的道德觀念、道德規範、道德 品質, 反映特定時空處境下的社會總體狀況。我們應關注個人道德 規範、行為模式背後所蓝涵的社會性涵義, 將個人放在社會處境中 考察。因此, 結構性倫理學視角的“個人道德”, 本質上是一種 “社 會道德”，而非 “個人私事”。

結構性倫理學另一基本特徵是 “社會結構性”, 而非單純的 “個 人化生活”。眾所周知, 道德哲學、道德觀念、道德風尚、道德規範、 道德品質、道德判斷和道德爭論的主要客體和直接服務物件都是個 人, 但這些人並非是獨立的個體, 行為也並非純粹的個體, 是宏觀 社會結構化處境與微觀結構化社會關係的社會行動者, 是宏觀社會 結構的典型表現。這意味個人既是結構化社會關係的重要組成部 分, 又是社會結構化互動關係的典型表現形式。需要指出的是, 本 文的社會結構是廣義的概念, 既包括廣義和宏觀取向的社會結構性 概念, 又包括中觀和組織性的社會性結構, 還包括微觀和個人的生 活結構、行動結構和意義結構。社會結構概念強調一個體系或系統 各組成部分之間的相互聯繫, 強調系統性與結構性互動。

結構性倫理學第三個重要特徵是，道德哲學、道德觀念、道德 風尚、道德規範和道德原則, 以及道德實踐和道德思想理論淵源的 多樣性和多元化，各式各樣思想觀念與實踐並存共生。例如當代中 國社會的倫理學傳統多種多樣, 中國古代道德哲學思想，近代西方 基督宗教倫理，近代萌芽的資本主義商業倫理道德，馬克思主義思 想與革命倫理, 前蘇聯社會主義倫理道德, 現代社會道德哲學, 後 現代社會倫理道德，以及各民族、各國家各種倫理道德並存共生。28

(27) 彼得 ·伯格(Peter L. Berger)、湯瑪斯 · 盧克曼(Thomas Luckmann)著, 汪 湧譯 : 《現實的社會構建》( 北京: 北京大學出版社, 2009 年) , 頁 15 。

(28) 孫慕義: 《後現代生命神學: 生命倫理學的概念圖式與終結讋論》(高雄: 文鋒文 化事業有限公司, 2007 年), 頁 3。 
多樣性與多元化既可是結構分化與專業化較低表現, 又可是高度結 構分化與專業化的結果。

結構性倫理學第四項重要特徵是群體性與行業性, 社會性、結 構化和多樣化的社會互動關係具體體現在某類社會群體或某種行業 實踐中。群體性主要是指某類社會亞群體成員所具有的共同性特 徵, 社會亞群體的群體生活形態多姿多彩, 三百六十行泛指各行各 業群體生活。改革開放三十年來, 中國社會由高度統一, 一致和全 國各地 “一模一樣” 演變為多種多樣狀況, 東部、中部、西部地區居 民，城市市民、鄉村農民和億萬城鄉間流動農民工群體，各式各樣 的政府機關、事業單位、國營企業、外資企業和民營企業工作單位, 行政管理、國家發展與改革系統、財税系統、教育系統、衞生系統, 社會福利、醫藥衞生和文化體育行業間的差異愈來愈大, 社會不平 等與社會不公平主要表現為各群體、各行業之間的不平等和不公 平。29更為重要的是, 相對於西方古典個人主義和中國改革開放前 的集體主義思想, 目前社會結構轉型過程中的中國社會產生一種獨 特的“組織性個人主義”，工作單位的性質、地位、資源和權力 “決 定” 個人的生活狀況, 同時個人特質和個人能力也開始對個人生活產 生重要影響。

結構性倫理學第五項重要特徵是歷史時代性和文化相對性特 徵, 歷史時代性特徵主要反映某一歷史發展階段性特點, 文化相對 性主要反映道德哲學與倫理實踐的社會相對性特點。改革開放三十 年來, 中國社會結構全面轉型, 突顯了當代中國社會發展所有的歷 史階段性特徵, 中國社會處於由 “傳統社會” 向 “現代社會”轉型的過 渡時期，道德哲學與倫理同樣轉型過渡。中國集體主義思想與道德 哲學, 正由組織性個人主義階段, 向西方和現代個人主義轉型。同 時, 中國道德哲學與倫理思想具有鮮明突出和不同於西方的中國社 會文化傳統特徵, 以和為貴, 中庸之道, 天人合一, 差序格局, 扶

(29) 劉繼同：〈組織性個人主義：社會轉型期中國社會的福利文化與理論框架〉, 《中 國社會科學評論》, 2004 年, 第 2 期, 頁 6 。 
危濟困和守望相助, 境遇性傳統性色彩濃厚。30 簡言之, 歷史時代 性和文化相對性特徵反映結構化與生活化社會互動關係的重要本質 屬性。

中國結構主義道德哲學思想與結構性倫理學原則體系的形成發 展並非偶然, 而是近現代百多年中國政治革命、經濟革命、社會革 命、文化革命和道德革命實踐的綜合性歷史產物, 典型反映中國道 德哲學, 尤其是由傳統農業社會向現代工業社會全面性、結構性轉 型的狀況。1840年鴉片戰爭以來, 中國逐漸淪為半封建半殖民社會, 民族主權受到空前挑戰。辛亥革命和中華民國, 尤其是 1949 年中華 人民共和國成立, 標誌中國近代政治革命的完成。1978 年中國確立 以經濟建設為中心，實施改革開放政策，使中國初步建立市場經濟 體制，市場體系開始成為配置社會資源和創造物質財富基本結構性 力量，基本完成經濟革命任務。同時，1919年“五四” 新文化運動、 1920-30 年代中國 “社會性質與農村社會性質” 論戰、抗日戰爭時期的 “抗日救國” 文化、1966-1976年文化大革命以及改革開放以來的 “解 放思想”, 實際上都是全國性文化思想革命和道德革命的運動, 結果 形成今天的結構主義倫理狀況。需要強調的是, 1840 年以來, 政治 與倫理道德, 政治的合法性與合理性等關係問題, 如國家、市場與 公民社會關係, 民族主權國家建構與民族國家獨立, 政治決策與社 會善治這些議題, 都是推動傳統封建主義倫理學向結構轉型時期結 構性倫理學轉型發展的主要動因。31這意味中國近現代政治哲學、 法律哲學、治國理政方針的政策模式，決定了道德哲學和倫理模式； 而政治哲學、法律哲學、治國理政方針的政策發展狀沉則決定了道 德哲學與結構性倫理學的發展狀況。

(30) 約瑟夫. 弗萊徹 (Joseph F. Fletcher)著, 程立顯譯 : 《境遇倫理學 : 新道德論》(北 京: 中國社會科學出版社, 1989 年), 頁 2 。

(31) 單繼剛等著: 《政治與倫理一一應用政治哲學的視角》(北京: 人民出版社, 2006 年), 頁 $1-3$ 。 


\section{五、結構主義生命倫理學對中國醫藥衞生體制改革政策 之意義}

結構性倫理學對當代中國醫藥衞生體制改革實踐具有特別重要 和豐富多彩的政策涵義。首先，從政治哲學決定道德哲學，政治倫 理決定社會倫理的角度看, 政治哲學和政治倫理深刻影響、決定道 德哲學與社會倫理，“好”的衞生保健體系與衞生政策決定醫學專業 精神。32 其次, 中國政治體制改革進程與總體規劃, 尤其是醫藥衞 生體制改革總體規劃與發展藍圖，深刻影響和決定道德哲學與生命 倫理學，醫藥衞生體制改革品質決定生命倫理學品質。33 第三，結 構性倫理學的社會性特徵要求我們, 將生命倫理學、醫學道德規範 與醫學專業精神等議題放在中國社會處境中考慮, 不能脱離中國社 會處境來討論抽象的醫學倫理。34與此同時, 結構性倫理學的社會 性和系統性特徵要求我們從社會系統結構功能角色的角度, 全面以 系統科學理解轉型過程中的生命倫理學和道德哲學, 尤其是醫學專 業精神的主要議題。第四, 結構性倫理學的結構化特徵要求我們, 將醫務人員的行為規範和倫理道德觀念放在更宏觀的社會結構中去 觀察，尤其是注重醫務人員的道德風尚、道德規範與國家政治哲學、 政治倫理、商業倫理以致更廣泛多樣的社會倫理之間的互動關係， 更好地理解宏觀的社會結構、道德哲學結構以決定個人行為結構和 生活結構的規律，推動譴責個人文化轉為制度建設文化。35這意味 著醫護人員諸多道德失範、倫理不端行為的主要成因是宏觀的社會 結構。第五，結構性倫理學的多樣化特徵要求我們，越是在思想混 亂、道德哲學危機四伏的背景下，我們越應高舉公平、正義、平等、

(32) 劉繼同：〈甚麼是“好”的衞生政策? 〉, 《中國醫院管理》, 2007 年, 第 4 期, 頁 3 。

(33) 劉繼同：〈論醫藥衞生體制改革質量〉, 《衞生經濟研究》, 2010 年, 第 11 期, 頁 13 。

(34) 劉繼同: 〈中國醫學人文、醫學專業精神的主要研究議題與制度化決定因素〉, 《中 國衞生政策研究〉, 2009 年, 第 2 卷, 第 10 期, 頁 56-57。

(35) 劉繼同: 〈衞生改革困境成因的系統結構分析與宏觀戰略思考〉, 《中國衞生經濟》, 2005 年, 第 11 期, 頁 19 。 
自由、權利、善目、德性、保密、尊重和改善病人福利等道德大旗 與倫理原則, 奉行希波克拉底的宣言(The Hippocrates Oath), 努力踐 行醫學專業精神, 重建病人信任。36第六, 結構性倫理學的群體性 與行業性特徵提醒我們, 醫藥衞生領域是由價值引導的社會服務行 業。醫療衞生服務背後藴涵的價值目標與價值基礎, 及其追求的價 值理念, 是醫學專業精神最重要的組成部分, 是醫療衞生服務的 “靈 魂” 和精髓, 戰略地位格外重要。有鑒於此, 我們應大力加強醫學生 醫學人文教育, 培養醫學專業精神, 同時將社會工作者與社會福利 制度等制度化人文機制引入醫療衞生服務領域, 以適應生物醫學模 式的轉型需要。37第七, 結構性倫理學的社會性、結構性、系統性 和制度化建設內在規律性特徵提醒我們, 要從根本解決中國醫藥衞 生體制改革的倫理學困境。最重要的制度化建設思路有二, 一是恢 復醫療衞生事業的 “社會福利” 性質, 二是加強公共福利財政與衞生 財政制度建設，從福利制度性質和衞生保健財政制度建設的角度， 徹底解決醫護人員職業道德危機的問題。38

\section{六、結論}

中國醫藥衞生體制改革實踐正面臨前所未有的結構性困境，生 命倫理學的結構性困境既是中國醫藥衞生體制改革總體性結構性困 境的重要組成部分, 又是總體性結構性困境的重要表現形式, 更被 某些人 “錯誤地” 看作醫患關係結構性緊張和醫護人員職業道德下降 的主因, 他們似乎假定了醫護人員的職業道德高尚, 如此中國普遍 存在之 “看病貴、看病難” 的問題就不復存在。因此, 生命倫理學成 為觀察中國醫藥衞生體制改革和醫患關係結構性緊張困境的最佳視

(36) 劉繼同: 〈中國醫學人文內涵結構與醫務社會工作制度建設》〉, 《醫學與社會》, 2010 年, 第 7 期, 頁 $11-13$ 。

(37) 劉繼同: 〈構建和諧醫患關係與醫務社會工作的專業使命》〉, 《中國醫院管理》, 2006 年, 第 3 期, 頁 15 。

(38) 劉繼同: 〈衞生財政學概念的涵義、範圍領域、基本特徴與地位作用〉, 《中國衞 生經濟》, 2008 年, 第 1-3 期, 頁 5-7、10-13 及 9-11。 
角。更重要的是, 中國在經濟全球化和世界各國面臨醫藥衞生體制 改革的處境下, 加上改革開放三十二年, 其醫藥衞生體制改革的實 踐經驗與生命倫理學的結構性困境狀況, 可為我們研究全球性倫理 和全球生命倫理學提供恰當和典型的案例, 因而具有特別重要的社 會現實意義、理論意義、政策意義、專業學科建設意義和全球性意 義, 這是我們關注本議題的主要因素。

本文採取文獻回顧和衞生政策比較研究的方法, 從道德哲學和 “理想模型” 演變的角度, 首先簡略回顧西方社會道德哲學和個人主 義生命倫理學典範的歷史演變過程, 將西方社會的前哲學階段、古 希臘時期、中世紀教會時期、工業化革命階段、現代社會和後現代 社會的倫理模式分別概括為自然倫理、生活方式、神聖戒律、經濟 人型、個人主義和多樣化型模式, 清晰描繪西方社會倫理道德模式 由統治者是否具有德性, 演變為公民個人主義倫理學軌跡。無論是 統治者的德性, 還是現代公民的個人責任、權利、義務倫理, 道德 行為主體都是個人。與此相反, 中國歷史悠久、源遠流長的傳統美 德和道德哲學的歷史發展軌跡不同於西方社會, 中國春秋戰國、西 漢以後、三國以後、1840 年鴉片戰爭後、1919 五四運動前後分別形 成了生活情理為主的儒家倫理, 功德圓滿為主的佛教倫理, 自我發 展為主的道家倫理, 基督教倫理為主的社會倫理, 商業倫理為主的 職業道德, 馬克思主義與社會主義為主的革命倫理道德。總體來説, 除追求自我發展和自我完善的道家倫理之外, 中國各種不同類型道 德哲學和行為規範的共同之處是 “群體性倫理學”。這與西方社會的 個人主義倫理學迥然不同, 反差強烈。即使在改革開放三十二年後, “群體性倫理學” 和 “群體性福利文化” 仍然具有相當的解釋力。最 為重要的是, 中西方道德哲學與倫理模式比較研究的目的是提出 “結 構性倫理學模式”。

結構性倫理學模式既是本文的主體部分, 又是本文論述的戰略 重點, 主要目的是將 “結構” 和 “社會結構” 的概念引入道德哲學和倫 理學研究議程, 就像以往將 “結構” 和 “社會結構”引入歷史和其他社 
會科學研究領域一樣, 為 “社會系統觀” 增添嶄新的結構性要素 39 。 結構性倫理學是筆者創造的新概念，泛指從社會系統、社會結構和 社會互動關係角度看待道德哲學與道德規範的觀點和原則的總和。 與結構性倫理學對應的是個人主義倫理學思想。本文首次嘗試將結 構性倫理學的構成要素劃分為六個主要方面，一是存在主義道德哲 學，二是現實主義、集體主義和社會系統的性質，三是研究目標主 要關注現實的客觀狀況，而非理想性的“應當”狀態，四是研究範圍 廣泛，內容繁多，核心是將道德哲學與道德規範放在更宏觀的社會 處境、社會結構與社會體系中觀察，特別強調道德與社會生活互動 關係 40 , 五是結構性倫理學的研究方法應當是跨學科、跨行業、跨 部門的，旨在探索道德普遍規律，六是結構性倫理學的主要功能作 用不僅是解釋世界，還有改造世界，增進人們的福祉。與此相關， 本文從比較研究角度，著重論述結構性倫理學的“社會性或社會 化”，“社會結構性”，“多樣性和多元化”，“群體性與行業性”，“歷 史時代性和文化相對性”六大顯著特徵, 從中國近現代百多年政治經 濟革命、社會革命和文化革命角度, 解釋結構性倫理學的成因。

最後，筆者運用結構性倫理學原理和特徵，簡要闡述結構性倫 理學原則對解決中國醫藥衞生體制改革結構性困境和生命倫理學困 境的意義，如促進和諧醫患關係、加強醫學人文關懷和醫學專業精 神、建設豐富多彩的理論政策等，為醫藥衞生體制改革指明制度化 的發展方向。

(39) Stanford, Michael. The Nature of Historical Knowledge (Oxford: Blackwell, 1995) 1-5. (40) 切克蘭德 (Peter Checkland) 著, 左曉斯等譯 : 《系统論的思想與實踐》(北京: 華 夏出版社, 1990 年), 頁 1-3。

本文是劉繼同博士主持的國家社科基金項目(10BSH060)《中國特色醫務社會工作實務 模式研究》、世界衞生組織與聯合國兒童基金會聯合資助課題《中國衞生保健財政體 制現狀與對策研究》和北京大學宗教文化研究院資助啟動專案《當代中國重大宗教政 策問題實證研究》的終期成果之一，特此説明與致謝。

筆者誠摰感謝香港浸會大學應用倫理學研究中心提供的寶貴學習機會, 尤其欣賞香港 城市大學范瑞平教授、香港浸會大學張穎博士、北京協和醫學院張新慶博士、中南財 經政法大學張舜清博士的精彩點評和睿智建議。 


\section{參考文獻}

中國社會科學院哲學研究所《哲學研究》編輯部、中國哲學史研究室編:《中

國哲學史研究集刊(第二輯)》, 上海：上海人民出版社，1982 年。

切克蘭德(Peter Checkland)著, 左曉斯等譯 : 《系統論的思想與實踐》, 北京 :

華夏出版社, 1990 。

亨利. 西季威克 (Henry Sidgwick)著, 廖申白譯 : 《倫理學方法》, 北京: 中 國社會科學出版社, 1993 年。

李 奇：《道德與社會生活》, 上海：上海人民出版社，1984 年。

李傳斌：《條約特權制度下的醫療事業：基督教在華醫療事業研究 (1835-1937)》, 長沙：湖南人民出版社，2010年。

亞里斯多德(Aristotle)著, 苗力田譯: 《尼各馬科倫理學》, 北京: 中國社會 科學出版社, 1990 年。

彼得 ·伯格(Peter L. Berger)、湯瑪斯 · 盧克曼(Thomas Luckmann)著, 汪湧 譯：《現實的社會構建》, 北京：北京大學出版社, 2009。

邱仁宗：〈第八屆世界生命倫理學大會關於醫學專業精神和醫患關係研討內 容綜述〉, 《中國醫學倫理學》, 2007 年, 第 2 期, 頁 3-6。

查理斯 · L · 坎默(Charles L. Kammer III)著, 王穌平譯：《基督教倫理學》, 北京：中國社會科學出版社，1994 年。

派翠克 ·貝爾特 (Patrick Baert) 著, 篗鐵鵬譯 : 《二十世紀的社會理論》, 上 海：上海譯文出版社, 2002 年。

約瑟夫·弗萊徹(Joseph F. Fletcher)著, 程立顯譯 : 《境遇倫理學 : 新道德論》, 北京：中國社會科學出版社，1989年。

范瑞平編：〈導言：中國生命倫理學研究：良好開端, 大有可為〉, 《中外

醫學哲學》, 2007 年 12 月, 第 5 卷, 第 2 期, 頁 $1-8$ 。

孫慕義：《後現代生命神學：生命倫理學的概念圖式與終結辡論》, 高雄： 文鋒文化事業有限公司, 2007 年。

孫樹印：〈新形勢下醫患糾紛處理模式探討〉, 《中醫藥管理雜誌》, 2011 年, 第 1 期，頁 8-9 。

恩格爾哈特(H. Tristram Engelhardt, Jr.)著, 范瑞平譯：《生命倫理學基礎(第 二版)》, 北京: 北京大學出版社, 2006 年。

馬歇爾 (Thomas H. Marshall)著, 劉繼同譯：《公民權與社會階級》, 北京: 國外社會學, 2003 年 1 期。

張錫勤、饒良倫、楊忠文編著：《中國近現代倫理思想史》, 哈爾濱：黑龍 江人民出版社，1984 年。

梅 因 (Sir Henry Sumner Maine)著, 沈景一譯：《古代法》, 北京：商務印 書館, 1984 年。

許志偉: 〈中國當前的醫療危機與醫護人員的專業責任和使命〉, 《醫學與哲 學》, 2006 年, 第 9 期, 頁 1-6。

麥金太爾(Alasdair MacIntyre) 著, 龔 群譯：《倫理學簡史》, 北京: 商務 印書館，2003 年。

單繼剛等: 《政治與倫理一應用政治哲學的視角》, 北京: 人民出版社, 2006 年。

斯科特 ·伯里斯(Scott Burris)著, 申衛星編：《中國衞生法前沿問題研究》, 北京：北京大學出版社, 2005 年。 
斯馬特(John Jamieson Carswell S mart)、威廉斯(Bernard Williams)著, 牟 斌譯：《功利主義：贊成與反對》, 北京：中國社會科學出版社, 1992 年。

趙美娟: 〈醫學人文關懷應關懷甚麼和怎樣關懷——美學視角下的人文關懷 建設〉, 《醫學與哲學》, 2005 年, 第 4 期, 頁 26-28。

劉繼同:〈中國醫學人文、醫學專業精神的主要研究議題與制度化決定因素〉, 《中國衞生政策研究》, 2009 年, 第 2 卷, 第 10 期, 頁 56-61。 :〈中國醫學人文內涵結構與醫務社會工作制度建設〉, 《醫學與社會》, 2010 年, 第 7 期, 頁 11-13。

:〈中國醫藥衞生體制改革困境與“醫療財政學”問題〉, 《中共寧波市 委黨校學報》, 2008 年, 第 4 期, 頁 24-27。

:〈甚麼是“好”的衞生政策? 〉, 《中國醫院管理》, 2007 年, 第 4 期, 頁 3-6。

:〈為甚麼衞生政策還不能成為“國策”? ’ 《中國衞生》, 2004 年, 第 7 期, 頁 $51-53$ 。

:〈組織性個人主義: 社會轉型期中國社會的福利文化與理論框架〉, 《中國社會科學評論》, 2004 年, 第 2 期, 頁 5-10。

: 〈構建和諧醫患關係與醫務社會工作的專業使命〉, 《中國醫院管理》, 2006 年，第 3 期，頁 15-19。

: 〈衞生改革困境成因的系統結構分析與宏觀戰略思考〉, 《中國衞生 經濟》, 2005 年，第 11 期，頁 19-22。

: 〈衞生改革的價值基礎與價值目標的宏觀戰略思考〉, 《衞生經濟研

究》, 2006 年, 第 3 期, 頁 3-4。

:〈衞生事業公益性與福利性定性的本質區別是甚麼? 〉, 《中國醫院 管理》, 2007 年, 第 8 期, 頁 4-8。

: 〈衞生財政學概念的涵義、範圍領域、基本特徵與地位作用(上、中、

下) 〉, 《中國衞生經濟》, 2008 年, 第 1-3 期, 頁 5-7、10-13 及 9-11。 :〈論醫藥衞生體制改革質量〉, 《衞生經濟研究》, 2010 年, 第 11 期, 真 13-15。

:〈醫學目的、衞生改革目標與建構和諧社會〉, 《西安外事學院學報》, 2006 年, 第 2 卷, 第 2 期, 頁 $17-24$ 。

Machan, Tibor R. Classical Individualism: The Supreme Importance of Each Human Being. London: Routledge, 1998.

Reimer, Joseph, Diana Pritchard Paolitto and Richard H. Hersh. Promoting Moral Growth: From Piaget to Kohlberg. $2^{\text {nd }}$ Ed. New York: Longman, 1983.

Stanford, Michael. The Nature of Historical Knowledge. Oxford: Blackwell, 1995. 